\title{
Common variables in European pancreatic cancer registries: The introduction of the EURECCA pancreatic cancer project
}

\author{
E.M. de Leede ${ }^{\text {a }}$, B.G. Sibinga Mulder ${ }^{a}$, E. Bastiaannet ${ }^{a}$, \\ G.J. Poston ${ }^{\mathrm{b}}$, K. Sahora ${ }^{\mathrm{c}}$, E. Van Eycken ${ }^{\mathrm{d}}$, Z. Valerianova ${ }^{\mathrm{e}}$, \\ M.B. Mortensen ${ }^{\mathrm{f}}$, H. Dralle ${ }^{\mathrm{g}}$, M. Primic-Žakelj ${ }^{\mathrm{h}}$, J.M. Borràs ${ }^{\mathrm{i}}$, \\ T. Gasslander ${ }^{j}$, A. Ryzhov ${ }^{k}$, V.E. Lemmens ${ }^{1}$, J.S.D. Mieog ${ }^{\mathrm{a}}$, \\ P.G. Boelens ${ }^{\text {a }}$, C.J.H. van de Velde ${ }^{\text {a,* }}$, B.A. Bonsing ${ }^{\text {a }}$ \\ ${ }^{a}$ Department of Surgery, Leiden University Medical Centre, Leiden, The Netherlands \\ ${ }^{\mathrm{b}}$ Department of Surgery, University Hospital Aintree, Liverpool, United Kingdom \\ ${ }^{c}$ Department of Surgery and Comprehensive Cancer Centre, Medical University of Vienna/ABCSG Pancreatic \\ Cancer Registry, Austria \\ d Belgian Cancer Registry, Brussels, Belgium \\ ${ }^{\mathrm{e}}$ Bulgarian National Cancer Registry/National Oncological Hospital, Sofia, Bulgaria \\ ${ }^{\mathrm{f}}$ Department of Surgery, Odense University Hospital/Danish Pancreas Cancer Group, Denmark \\ ${ }^{g}$ Department of Surgery, University of Halle-Wittenberg/Pancreatic Cancer Register, Halle, Germany \\ ${ }^{\mathrm{h}}$ Epidemiology and Cancer Registry/Institute of Oncology, Ljubljana, Slovenia \\ ${ }^{\mathrm{i}}$ Department of Clinical Sciences, University of Barcelona, Barcelona, Spain \\ ${ }^{\mathrm{j}}$ Department of Surgery, Linköping University/Swedish Registry for Pancreatic Tumors, Sweden \\ ${ }^{\mathrm{k}}$ National Cancer Registry of Ukraine/National Institute of Cancer, Kiev, Ukraine \\ ${ }^{1}$ Department of Research, Netherlands Cancer Registry/Comprehensive Cancer Centre The Netherlands (IKNL), \\ Eindhoven, The Netherlands
}

Accepted 10 March 2016

Available online 28 March 2016

\begin{abstract}
Background: Quality assurance of cancer care is of utmost importance to detect and avoid under and over treatment. Most cancer data are collected by different procedures in different countries, and are poorly comparable at an international level. EURECCA, acronym for European Registration of Cancer Care, is a platform aiming to harmonize cancer data collection and improve cancer care by feedback. After the prior launch of the projects on colorectal, breast and upper GI cancer, EURECCA's newest project is collecting data on pancreatic cancer in several European countries.

Methods: National cancer registries, as well as specific pancreatic cancer audits/registries, were invited to participate in EURECCA Pancreas. Participating countries were requested to share an overview of their collected data items. Of the received datasets, a shared items list was made which creates insight in similarities between different national registries and will enable data comparison on a larger scale. Additionally, first data was requested from the participating countries.

Results: Over 24 countries have been approached and 11 confirmed participation: Austria, Belgium, Bulgaria, Denmark, Germany, The Netherlands, Slovenia, Spain, Sweden, Ukraine and United Kingdom. The number of collected data items varied between 16 and 285. This led to a shared items list of 25 variables divided into five categories: patient characteristics, preoperative diagnostics, treatment, staging and survival. Eight countries shared their first data.
\end{abstract}

\footnotetext{
Abbreviations: EURECCA, European Cancer Audit; ECCO, European Cancer Organisation; ESSO, European Society of Surgical Oncology.

* Corresponding author. Department of Surgery, K6-50 Leiden University Medical Center, P.O. Box 9600, 2300 RC Leiden, The Netherlands. Tel.: +31 71526 2309; fax: +3171526 6750 .

E-mail address: c.j.h.van_de_velde@lumc.nl (C.J.H. van de Velde).
} 
Conclusions: A list of 25 shared items on pancreatic cancer coming from eleven participating registries was created, providing a basis for future prospective data collection in pancreatic cancer treatment internationally.

(C) 2016 Elsevier Ltd. All rights reserved.

Keywords: Pancreatic cancer; Registry; Audit; EURECCA; Quality assurance

\section{Introduction}

Pancreatic cancer is associated with a poor prognosis for most patients. In trial populations a median survival of 23 months for initially resectable tumours in combination with neoadjuvant therapies was reached. ${ }^{1}$ Over time, an increase of prescribed chemotherapy was observed in the Netherlands for patients with and without metastatic pancreatic cancer, without any benefit of survival. ${ }^{2}$ Capturing data on cancer outcome is crucial to detect over and under treatment in pancreatic cancer. Variations in incidence and mortality between European countries have been described previously., 3,4 Because survival might, besides lifestyle habits (such as smoking) and genetic differences, also be influenced by variances in treatment, structural international comparison would increase insight in 'best practices' in pancreatic cancer. Auditing cancer care with adequate case-mix adjustments is a very effective instrument with impact on outcome. For example, in rectal cancer, national audits were able to implement total mesorectal excision (TME), reducing local recurrence and variation in other outcome parameters within countries., Patterns of care can be identified and communicated to hospitals or physicians. ${ }^{5,7,8}$ Feedback generates optimization of treatment standards and (neo)adjuvant therapy and could avoid over and under treatment. Moreover, an important advantage of registries over clinical trials is that audit registries include the entire patient population which offers the opportunity to study patient groups that are usually excluded from clinical trials (e.g. elderly, high comorbidity). ${ }^{5}$ However, registries across Europa differ and can therefore not easily be compared. ${ }^{9}$ A 2013 EUROCHIP survey (European Cancer Health Indicators Project) showed that cancer registry data are a reliable source for evaluation and strategy planning, but not all data is available in every registry, impeding a complete comparison. ${ }^{9}$ To create uniformity in the collected data and to enable a robust international comparison and report on outcomes, the European Society of Surgical Oncology (ESSO) and the European CanCer Organisation (ECCO) initiated an international, multidisciplinary, outcome-based quality improvement program: European Registration of Cancer Care (EURECCA). The EURECCA projects collaborate with existing national audits and cancer registries. ${ }^{10-12}$ Following EURECCA Colorectal, Breast and Upper GastroIntestinal (GI), EURECCA Pancreas focusses on pancreatic cancer and is following the roadmap of the previous projects. The first step in the EURECCA Pancreas project is to describe a common data item list among the responding European countries. The data items will provide the basis for the design of the future prospective international comparison EURECCA Pancreas project.

\section{Methods}

From the start of EURECCA Pancreas, 36 (pancreatic) cancer registries have been approached and invited to join the EURECCA Pancreas platform and $44 \%$ responded $(\mathrm{n}=16)$. Reasons for not collaborating were the absence of a well-functioning cancer registry or no available data because the registry started only recently. Eleven European countries agreed to participate in this comparison. An overview of variables that are collected on each patient, was requested. All recorded data items were compared in a database and matching items were scored. If items were present in the database or could be calculated using other items in the database, they were marked 'present' in the shared items comparison. If an item was present in 7 or more datasets, it was marked as a 'shared item'. After all the items were entered in the database, a report was sent back to the national data managers to check for errors or incompleteness. The corrected lists were returned and processed in the database. Most audit registries described in this article have given their full commitment to participate in the EURECCA framework by approval of the Call For Agreement.

\section{Results}

Eleven complete lists of items were received from the collaborators; Austria, Belgium, Bulgaria, Denmark, Germany, The Netherlands, Slovenia, Spain, Sweden, Ukraine and the United Kingdom. Besides national or regional cancer registries $(\mathrm{n}=5)$, several pancreatic cancer specific cancer audits $(\mathrm{n}=6)$ in Europe supplied lists with recorded data items. Table 1 presents the eleven participating registries in this study. The number of collected items differs between the different countries, from 16 to 285 . This is also depending on whether the registry is a national cancer registry or a specific registry on pancreatic cancer. Four registries have registered all patients diagnosed with pancreatic cancer, including the data on palliative treatment. The other seven registries are general cancer registries or surgical registries. Therefore it was decided that mainly the variables concerning surgically treated patients could be used. This resulted in a total of 25 items that are available for most of the countries. These items are displayed in Table 2, they were divided into five 
Table 1

Characteristics of the participating registries; the EURECCA consortium.

\begin{tabular}{|c|c|c|c|c|c|}
\hline Country & Audit & Since & Type of registry & National/regional data & Numbers of items \\
\hline Austria & ABCSG registry for pancreatic cancer ${ }^{13}$ & 2010 & Pancreatic Cancer & National $^{\mathrm{a}}$ & 37 \\
\hline Belgium & National Cancer Registry & 2005 & Cancer & National & 51 \\
\hline Bulgaria & National Cancer Registry & 1952 & Cancer & National & 76 \\
\hline Denmark & Danish Pancreatic Cancer Database & 2007 & Pancreatic cancer & National & 36 \\
\hline Germany & Halle/Magdeburg & 2010 & Pancreatic cancer & Regional & 128 \\
\hline \multirow[t]{2}{*}{ The Netherlands } & Dutch Pancreatic Cancer Audit & 2013 & Pancreatic cancer & National $^{\mathrm{b}}$ & 130 \\
\hline & Netherlands Cancer Registry & 1989 & Cancer & National & \\
\hline Slovenia & Cancer Registry of Republic of Slovenia & 1950 & Cancer & National & 50 \\
\hline Spain & Catalonian Pancreatic Cancer Audit & 2013 & Pancreatic cancer & Regional $^{\mathrm{c}}$ & 82 \\
\hline Sweden & National Quality Register for Pancreatic cancer & 2010 & Pancreatic cancer & National & 285 \\
\hline Ukraine & National Cancer Registry Ukraine & 1996 & Cancer & National & 16 \\
\hline United Kingdom & AUGIS HPB cancer registry & 2009 & Pancreatic cancer & National & 54 \\
\hline
\end{tabular}

${ }^{a}$ Six centres operating on pancreatic cancer.

b National audit, data from one high volume centre.

c Six parallel pancreatic cancer audits.

subcategories: patient characteristics, diagnostics, treatment, staging and survival.

Additionally, eight of the participating collaborators have shared their raw data. Six collaborators shared data from patients included in 2012 or 2013, Belgium shared data from patients diagnosed with pancreatic cancer between 2004 and 2013 and Denmark shared data from patients diagnosed with pancreatic cancer between 2011 and 2015. An example of their data is demonstrated in the Appendix.

Table 2

Shared items in eleven participating registries of the EURECCA Pancreas consortium.

\begin{tabular}{ll}
\hline Category & Data item \\
\hline Patient demographics & Gender \\
& Patient number \\
& Patient name \\
& Age/Date of birth \\
& ASA or ECOG or WHO performance status \\
& CT \\
Diagnostics & ERCP \\
& Date of diagnosis/Date of incidence \\
& Localization (Caput, Corpus, Cauda, etc.) \\
& Diagnosis cytology or histology \\
& (ICD-morphology) (Adenocarcinoma, \\
& Neuroendocrine, IPMN, etc.) \\
& Type of neoadjuvant therapy \\
& Date of surgery \\
Treatment & Type of surgery (PPPD, Whipple, distal/total, etc.) \\
& Vascular resection/reconstruction \\
& Complications \\
& Date of discharge/Duration of stay \\
& Postoperative radiotherapy \\
& Postoperative chemotherapy \\
& Postoperative radio-chemotherapy \\
Survival & Date of start adjuvant therapy \\
& pT \\
pN \\
pM \\
Resection margin: R0/R1/R2 \\
Date of death \\
& \\
&
\end{tabular}

\section{Discussion}

Audit and registry structures have led to greater improvements in cancer care outcome than trial and drug development. EURECCA, the European cancer audit, is a valuable collaborative platform to increase our insights on performances in cancer care. Especially for pancreatic cancer with its aggressive biological behaviour it is crucial to collaborate on collecting data, from treatment to outcome.

Capturing clinical relevant international benchmarks is not challenged before and would provide tools for feedback. Experience gained by all participants during years of setting-up (pancreatic) cancer registries and collecting data of patients, is combined in this new EURECCA project. Combining forces and collecting population-based data will represent the actual patterns of care, more than results from clinical trials. International comparisons are the superlative measure to effectively benefit patients with pancreatic cancer.

A common dataset that covers all shared aspects concerning pancreatic cancer and its treatment is identified. A core dataset formation is the next step. For instance optimisation of the dataset by adding 'date of diagnose', 'clinical TNM stage' and 'CA19.9' would form the template of future comparisons. Important information about the current common dataset and the planned core dataset is that no individual physician or hospital specific data will be incorporated during future analysis; in no way it will be a name and shame report.

In EURECCA colorectal and EURECCA upper GI, common data items were included if present in 6 out of 7 respectively 8 out of 9 participating registries. ${ }^{10,12}$ In EURECCA Pancreas presence in 7 out of 11 datasets was set as a limit, to achieve a more complete dataset. A limitation of this dataset is that in contains no information on non-surgically treated patients. Often the data collections are surgical driven and no data on solely palliative treated patients is registered. Not all audits or registries are population-based, containing data on all consecutive pancreatic cancer patients; 3 registries only collect data on surgically treated patients. In other registries, data from 
patients treated in a group of collaborating centres is collected. The coverage of the patients included in these audits might not be as complete as a national cancer registry, although several of them cover a majority of hospitals in a specific territory.

In the near future a retrospective analysis is planned with merged data from the collaborating registries. Differences in age, gender, incidence, tumour stage and differences in treatment can be identified. Also elderly patients are included in the EURECCA projects and consequently care patterns for the elderly pancreatic cancer patients can be analysed. The aggressive tumour biology and the late onset of complaints and consequently the late presentation of patients, result in high percentages of advanced stage disease and less therapeutic options. Only (borderline) resectable patients, the smallest group, are expected to be discussed in the tumour boards. Locally advanced pancreatic cancer patients, as well as metastasized patients are often directed to the medical oncologist. In future registry or audit structures of all stages should be combined to have a clear view of the medical decision making, clinical care pathways and treatment strategies in the different collaborating countries. By calculating with the date of diagnosis and date of surgery, waiting times for surgery or start of neoadjuvant treatment can be calculated. If patients are treated, neoadjuvant therapies impact on pathological responses, so it is very important to stratify for clinical stage before therapy starts. Pre-treatment TNM stages can then be compared to postoperative pathology reports on TNM stage, to unravel information about medical decision making in pancreatic cancer.

In conclusion, a common dataset is identified for this new EURECCA Pancreas project. Establishing a core dataset is the next step. Among our future perspectives, a prospective international auditing of pancreatic cancer will be designed in a collaborative way respecting high data security and ethical analysis.

\section{Conflict of interest statement}

The authors have no conflict of interest.

\section{Acknowledgements}

We would like to thank all our contacts at the participating registries, who collaborate in this challenge.

EURECCA foundation is supported with a grant from ESSO. Appendix 1. Shared items in eight participating regis-
tries of the EURECCA Pancreas consortium.

\begin{tabular}{|c|c|c|c|c|c|c|c|c|c|}
\hline & & \multicolumn{4}{|l|}{ Registries } & \multicolumn{4}{|l|}{ Audits } \\
\hline & & Slovenia & Bulgaria & Ukraine & Belgium & $\begin{array}{l}\text { Netherlands } \\
\text { (Leiden) }\end{array}$ & $\begin{array}{l}\text { Spain } \\
\text { (Catalonia) }\end{array}$ & Austria & Denmark \\
\hline \multirow{2}{*}{\multicolumn{2}{|c|}{$\begin{array}{l}\text { Year } \\
\text { Registry }^{\mathrm{a}}\end{array}$}} & 2012 & 2013 & 2013 & $2004-2013$ & 2013 & 2013 & 2013 & $2011-2015^{\mathrm{a}}$ \\
\hline & & $\begin{array}{l}\text { Cancer } \\
\text { Registry } \\
\text { of Republic of } \\
\text { Slovenia }\end{array}$ & $\begin{array}{l}\text { BNCR: } \\
\text { Bulgarian } \\
\text { National } \\
\text { Cancer } \\
\text { Registry }\end{array}$ & $\begin{array}{l}\text { NCRU: } \\
\text { National } \\
\text { Cancer } \\
\text { Registry of } \\
\text { Ukraine }\end{array}$ & $\begin{array}{l}\text { BCR: Belgian } \\
\text { Cancer } \\
\text { Registry }\end{array}$ & $\begin{array}{l}\text { DPCA: } \\
\text { Dutch } \\
\text { Pancreatic } \\
\text { Cancer } \\
\text { Audit }\end{array}$ & $\begin{array}{l}\text { Pancreatic } \\
\text { Surgery } \\
\text { Clinical } \\
\text { Audit Catalan }\end{array}$ & $\begin{array}{l}\text { ABCSG } \\
\text { registry for } \\
\text { pancreatic } \\
\text { cancer }\end{array}$ & $\begin{array}{l}\text { DPCD: } \\
\text { Danish } \\
\text { Pancreatic } \\
\text { Cancer } \\
\text { Database }\end{array}$ \\
\hline \multicolumn{2}{|c|}{ Organisation $^{\mathrm{a}}$} & $\begin{array}{l}\text { Population } \\
\text { based }\end{array}$ & $\begin{array}{l}\text { Population } \\
\text { based }\end{array}$ & $\begin{array}{l}\text { Regions and } \\
\text { central } \\
\text { database }\end{array}$ & $\begin{array}{l}\text { Population } \\
\text { based }\end{array}$ & $\begin{array}{l}\text { Cancer } \\
\text { registry }\end{array}$ & Clinical audit & - & $\begin{array}{l}\text { National } \\
\text { cancer } \\
\text { registry }\end{array}$ \\
\hline \multicolumn{2}{|c|}{ Data collection $^{\mathrm{a}}$} & $\begin{array}{l}\text { Per centre, } \\
\text { data managers }\end{array}$ & $\begin{array}{l}13 \text { regional } \\
\text { centres; } 1 \\
\text { BNCR } \\
\text { central } \\
\text { database }\end{array}$ & $\begin{array}{l}\text { Regional } \\
\text { centre, } \\
\text { registrars }\end{array}$ & $\begin{array}{l}\text { Per centre, } \\
\text { data managers }\end{array}$ & $\begin{array}{l}\text { Per centre, } \\
\text { data } \\
\text { managers }\end{array}$ & $\begin{array}{l}\text { Per centre, } \\
\text { data managers }\end{array}$ & - & $\begin{array}{l}\text { Per centre, } \\
\text { data managers }\end{array}$ \\
\hline \multicolumn{2}{|c|}{ Centralisation of surgery ${ }^{a}$} & 2 hospitals & No & 40 hospitals & No & 20 hospitals & 10 hospitals & - & 4 hospitals \\
\hline \multicolumn{2}{|c|}{ Inhabitants $(\times 10 \times 6)$} & 2 & 7.3 & 45 & 11 & 17 & 7.5 & - & 5.7 \\
\hline \multicolumn{2}{|l|}{$\mathrm{Nr}$ patients } & 356 & 1256 & 5597 & 13368 & 79 & 207 & + & 2464 \\
\hline \multirow[t]{2}{*}{ Sex } & Male & 183 & 731 & 3028 & 6910 & 37 & 116 & \multirow{2}{*}{+} & 1279 \\
\hline & Female & 173 & 525 & 2569 & 6458 & 42 & 91 & & 1185 \\
\hline Age & & & 68.2 & 66.2 & 69 & 64.2 & 67.5 & + & 68.5 \\
\hline $\begin{array}{l}\text { Nr patients } \\
\text { surgery }\end{array}$ & Total & $47[13 \%]$ & $401[32 \%]$ & $816[15 \%]$ & + & 79 & 207 & + & $433[18 \%]$ \\
\hline $\begin{array}{l}\text { ASA or ECC } \\
\text { performan }\end{array}$ & $\begin{array}{l}\text { or WHO } \\
\text { tatus }\end{array}$ & - & - & - & + & + & - & - & + \\
\hline \multicolumn{10}{|l|}{ Diagnostics } \\
\hline \multirow{2}{*}{$\begin{array}{r}\text { Diagnostic } \\
\text { imaging }\end{array}$} & $\mathrm{CT}$ & $60 \%$ & - & - & + & $77(98 \%)$ & - & \multirow[t]{2}{*}{+} & $90 \%$ \\
\hline & ERCP & $40 \%$ & - & - & + & - & - & & $10 \%$ \\
\hline
\end{tabular}


(continued)

\begin{tabular}{|c|c|c|c|c|c|c|c|c|c|}
\hline & & \multicolumn{4}{|l|}{ Registries } & \multicolumn{4}{|l|}{ Audits } \\
\hline & & Slovenia & Bulgaria & Ukraine & Belgium & $\begin{array}{l}\text { Netherlands } \\
\text { (Leiden) }\end{array}$ & $\begin{array}{l}\text { Spain } \\
\text { (Catalonia) }\end{array}$ & Austria & Denmark \\
\hline $\begin{array}{l}\text { Date of } \\
\text { diagnosis }\end{array}$ & & + & + & - & + & + & - & + & + \\
\hline \multirow[t]{5}{*}{ Localization } & Caput & $164[46 \%]$ & $608[49 \%]$ & $3121[56 \%]$ & + & $29[37 \%]$ & $166[80 \%]$ & - & $1336[54 \%]$ \\
\hline & Corpus & $22[6 \%]$ & $141[11 \%]$ & $512[9 \%]$ & & $9[11 \%]$ & $23[11 \%]$ & & $360[15 \%]$ \\
\hline & Cauda & $44[12 \%]$ & $66[5 \%]$ & $344[6 \%]$ & & $9[11 \%]$ & $18[9 \%]$ & & $303[12 \%]$ \\
\hline & Other & $15[4 \%]$ & $127[10 \%]$ & $356[6 \%]$ & & $13[17 \%]$ & 0 & & $228[9 \%]$ \\
\hline & Unknown & $113[32 \%]$ & 311 [25\%] & 1258 [23\%] & $50 \%$ & 19 [24\%] & 0 & & 237 [10\%] \\
\hline \multirow[t]{7}{*}{ ICD-morphology } & $\begin{array}{l}\text { Malignancy/ } \\
\text { carcinoma }\end{array}$ & $194[54 \%]$ & $593[47 \%]$ & $4009[72 \%]$ & + & - & $2[1 \%]$ & + & - \\
\hline & Adenocarcinoma & $88[25 \%]$ & $537[43 \%]$ & 1355 [24\%] & & $51[65 \%]$ & $71[34 \%]$ & & \\
\hline & $\begin{array}{l}\text { Ductal } \\
\text { adenocarcinoma }\end{array}$ & $48[13 \%]$ & $59[5 \%]$ & $61[1 \%]$ & & - & $87[42 \%]$ & & \\
\hline & Mucinous & $3[1 \%]$ & $33[3 \%]$ & $16[0.5 \%]$ & & $2[3 \%]$ & $20[10 \%]$ & & \\
\hline & Neuroendocrine & $22[6 \%]$ & $14[1 \%]$ & $21[0.5 \%]$ & & $3[4 \%]$ & - & & \\
\hline & Other & $3[1 \%]$ & $20[2 \%]$ & $135[2 \%]$ & & $10[12 \%]$ & $22[11 \%]$ & & \\
\hline & Unknown & $0[0 \%]$ & - & - & & $13[16 \%]$ & $5[2 \%]$ & & \\
\hline \multicolumn{10}{|l|}{ Treatment } \\
\hline Date of surgery & & + & + & + & + & + & + & + & + \\
\hline \multirow[t]{2}{*}{ Type of surgery } & $\begin{array}{l}\text { PPPD } \\
\text { Whipple } \\
\text { Other (total, tail } \\
\text { resection, etc.) }\end{array}$ & - & - & - & + & $\begin{array}{l}42[53 \%] \\
5[6 \%] \\
20[26 \%]\end{array}$ & $\begin{array}{l}31[15 \%] \\
167[81 \%] \\
9[4 \%]\end{array}$ & + & $\begin{array}{l}- \\
275[64 \%] \\
129[30 \%]\end{array}$ \\
\hline & Unknown & & & & & $12[15 \%]$ & - & & $29[6 \%]$ \\
\hline $\begin{array}{l}\text { Vascular } \\
\text { resection/ } \\
\text { reconstruction }\end{array}$ & & - & - & - & - & $7[9 \%]$ & - & + & $71[16 \%]$ \\
\hline Complications & & - & - & - & - & $33[42 \%]$ & $78[38 \%]$ & + & - \\
\hline $\begin{array}{l}\text { Date of } \\
\text { discharge/ } \\
\text { duration } \\
\text { of stay }\end{array}$ & & $\begin{array}{l}\text { Median: } 17 \\
\text { days }\end{array}$ & - & - & + & $\begin{array}{l}\text { Median: } 12 \\
\text { days }\end{array}$ & $\begin{array}{l}\text { Median: } 16 \\
\text { days }\end{array}$ & + & $\begin{array}{l}\text { Median: } 14 \\
\text { days }\end{array}$ \\
\hline \multirow{4}{*}{$\begin{array}{c}\text { Additional } \\
\text { therapy }\end{array}$} & Radiotherapy & $8[2 \%]$ & $4[0.3 \%]$ & $109[2 \%]$ & + & - & - & + & - \\
\hline & Chemotherapy & $72[20 \%]$ & $183[15 \%]$ & $752[13 \%]$ & + & $37[47 \%]$ & $6[3 \%]$ & - & $306[71 \%]$ \\
\hline & Chemo radiation & $2[1 \%]$ & - & & + & - & $6[3 \%]$ & - & - \\
\hline & Other & $0[0 \%]$ & - & & & - & - & & \\
\hline \multicolumn{10}{|l|}{ Staging } \\
\hline \multirow[t]{6}{*}{$\mathrm{pT}$} & 0 & $1[0.3 \%]$ & $6[1 \%]$ & $26[0.5 \%]$ & + & $1[1 \%]$ & 0 & + & $1[0.2 \%]$ \\
\hline & 1 & $6[2 \%]$ & $13[3 \%]$ & $57[1 \%]$ & & $3[4 \%]$ & $8[4 \%]$ & & $20[5 \%]$ \\
\hline & 2 & $10[3 \%]$ & $70[17 \%]$ & $704[13 \%]$ & & $5[6 \%]$ & $19[9 \%]$ & & $54[12 \%]$ \\
\hline & 3 & $27[8 \%]$ & $124[31 \%]$ & $2467[44 \%]$ & & $37[47 \%]$ & $108[52 \%]$ & & $342[79 \%]$ \\
\hline & 4 & $3[1 \%]$ & $163[41 \%]$ & 1351 [24\%] & & 0 & $6[3 \%]$ & & $13[3 \%]$ \\
\hline & Unknown & $311[87 \%]$ & $25[6 \%]$ & $992[18 \%]$ & & $33[42 \%]$ & $66[32 \%]$ & & $6[1 \%]$ \\
\hline \multirow[t]{3}{*}{$\mathrm{pN}$} & 0 & $12[3 \%]$ & $188[47 \%]$ & $2608[46 \%]$ & + & $24[30 \%]$ & $54[26 \%]$ & + & 149 [34\%] \\
\hline & $1(<)$ & $32[9 \%]$ & $187[47 \%]$ & $1997[36 \%]$ & & $31[40 \%]$ & $108[52 \%]$ & & $281[65 \%]$ \\
\hline & Unknown & $314[88 \%]$ & $26[6 \%]$ & $992[18 \%]$ & & $24[30 \%]$ & $45[22 \%]$ & & $3[0.6 \%]$ \\
\hline \multirow[t]{3}{*}{$\mathrm{pM}$} & 0 & $37[10 \%]$ & $223[56 \%]$ & 2731 [49\%] & + & $54[69 \%]$ & $20[10 \%]$ & + & 417 [96\%] \\
\hline & 1 & $12[3 \%]$ & $163[41 \%]$ & $1875[33 \%]$ & & $1[1 \%]$ & $2[1 \%]$ & & $15[3 \%]$ \\
\hline & Unknown & $309[86 \%]$ & $15[4 \%]$ & $991[18 \%]$ & & $24[30 \%]$ & $185[89 \%]$ & & $1[0.2 \%]$ \\
\hline \multirow{4}{*}{$\begin{array}{c}\text { Resection } \\
\text { margin }\end{array}$} & R0 & $29[60 \%]$ & 117 [29\%] & - & - & $45[57 \%]$ & $106[51 \%]$ & + & $362[84 \%]$ \\
\hline & $\mathrm{R} 1$ & $16[33 \%]$ & - & & & $21[27 \%]$ & $43[21 \%]$ & & $67[15 \%]$ \\
\hline & $\mathrm{R} 2$ & $2[4 \%]$ & - & & & - & - & & $3[0.6 \%]$ \\
\hline & Unknown & $1[3 \%]$ & - & & & $13[16 \%]$ & $58[28 \%]$ & & $1[0.2 \%]$ \\
\hline \multicolumn{10}{|l|}{ Survival } \\
\hline Date of death & & + & + & - & + & + & - & + & + \\
\hline Vital status & Death & $340[95 \%]$ & $1195[95 \%]$ & $4542[81 \%]$ & + & $48[60 \%]$ & - & + & + \\
\hline Follow-up until & & today & 12 months & 12 months & Dec. 2015 & today & 10 months & + & + \\
\hline
\end{tabular}

\footnotetext{
${ }^{\mathrm{a}}$ How the data is validated.
} 


\section{References}

1. Gillen S, Schuster T, Meyer Zum Buschenfelde C, Friess H, Kleeff J Preoperative/neoadjuvant therapy in pancreatic cancer: a systematic review and meta-analysis of response and resection percentages. PLoS Med 2010;7:e1000267.

2. Thomassen I, Lemmens VE, Nienhuijs SW, Luyer MD, Klaver YL, de Hingh IH. Incidence, prognosis, and possible treatment strategies of peritoneal carcinomatosis of pancreatic origin: a population-based study. Pancreas 2013;42:72-5.

3. Bosetti C, Bertuccio P, Malvezzi M, et al. Cancer mortality in Europe, 2005-2009, and an overview of trends since 1980. Ann Oncol - Off J Eur Soc Med Oncol ESMO 2013;24:2657-71.

4. Karim-Kos HE, de Vries E, Soerjomataram I, Lemmens V, Siesling S, Coebergh JW. Recent trends of cancer in Europe: a combined approach of incidence, survival and mortality for 17 cancer sites since the 1990s. Eur J Cancer 2008;44:1345-89.

5. van Gijn W, van de Velde CJ. Members of the Ec. Improving quality of cancer care through surgical audit. Eur J Surg Oncol - J Eur Soc Surg Oncol Br Assoc Surg Oncol 2010;36(Suppl. 1):S23-6.

6. Gatta G, Faivre J, Capocaccia R, Ponz de Leon M. Survival of colorectal cancer patients in Europe during the period 1978-1989. EUROCARE working group. Eur J Cancer 1998;34:2176-83.

7. van Leersum NJ, Kolfschoten NE, Klinkenbijl JH, Tollenaar RA, Wouters MW. 'Clinical auditing', a novel tool for quality assessment in surgical oncology. Ned Tijdschr Geneeskd 2011; 155:A4136.

8. McCulloch P. Surgical professionalism in the 21st century. Lancet 2006;367:177-81

9. Siesling S, Kwast A, Gavin A, Baili P, Otter REUROCHIP-3 Workpackage 5. Availability of stage at diagnosis, cancer treatment delay and compliance with cancer guidelines as cancer registry indicators for cancer care in Europe: results of EUROCHIP-3 survey. Int J Cancer - J Int du Cancer 2013;132:2910-7.

10. van Gijn W, van den Broek CB, Mroczkowski P, et al. The EURECCA project: data items scored by European colorectal cancer audit registries. Eur J Surg Oncol - J Eur Soc Surg Oncol Br Assoc Surg Oncol 2012;38:467-71.

11. Kiderlen M, Walsh PM, Bastiaannet E, et al. Treatment strategies and survival of older breast cancer patients - an international comparison between the Netherlands and Ireland. PLoS One 2015;10: e0118074.

12. de Steur WO, Henneman D, Allum WH, Dikken JL, et al. Common data items in seven European oesophagogastric cancer surgery registries: towards a European upper GI cancer audit (EURECCA upper GI). Eur J Surg Oncol - J Eur Soc Surg Oncol Br Assoc Surg Oncol 2014;40:325-9. http://dx.doi.org/10.1016/j.ejso.2013.11.021.

13. Gangl O, Sahora K, Kornprat P, et al. Preparing for prospective clinical trials: a national initiative of an excellence registry for consecutive pancreatic cancer resections. World J Surg 2014;38:456-62. 